\title{
OPTIMASI DESAIN RANGKA SEPEDA BERBAHAN BAKU KOMPOSIT BERBASIS METODE ANOVA
}

\author{
Ahmad Yakub ${ }^{1, *}$, Djoko W. Karmiadji ${ }^{2}$, Anwar Ilmar Ramadhan ${ }^{3}$ \\ ${ }^{1}$ Staf Pengajar Program Studi Teknik Mesin President University, Bekasi \\ ${ }^{2}$ Staf Pengajar Program Studi Magister Teknik Mesin Universitas Pancasila, Jakarta \\ ${ }^{3}$ Staf Pengajar Program Studi Teknik Mesin Universitas Muhammadiyah Jakarta, Jakarta \\ 1,*Email: yakub_dewantara@yahoo.co.id
}

Diterima: 1 September 2015

Direvisi: 29 September 2015

Disetujui: 6 Oktober 2015

\begin{abstract}
ABSTRAK
Pada dasarnya kriteria frame yang baik adalah memilki kekuatan dan kekakuan yang tinggi tetapi ringan dan mempunyai ketahanan terhadap korosi. Berdasarkan kriteria tersebut digunakanlah material komposit, dimana dapat diperoleh kriteria yang lebih baik dibandingkan dengan frame baja atau alumunium, Frame dapat dibuat lebih kuat dan ringan, tetapi yang lebih penting, desainer dapat mengontrol karakteristik pengendalian dan tidak dibatasi oleh penggunaan metal. Adapun tujuan dilakukan penelitian ini adalah menganalisa kondisi optimum desain rangka sepeda dengan metode Taguchi dan analisis ANOVA. Berdasarkan hasil analisis pengolahan data dengan kondisi desain optimum yg memberikan Tegangan Von Mises (MPa) yang besar adalah : A2 B2 C3 atau yang dilakukan perhitungan dengan kondisi desain menggunakan Seat Tube Angle sebesar $72^{\circ}$, dengan pergeseran Head Tube $0.2 \mathrm{~mm}$ dan beban pengendara sebesar $90 \mathrm{~kg}$. Analisis perhitungan dengan ANOVA untuk mengetahui pengaruh masing-masing faktor terhadap perhitungan Tegangan Maksimum pada sepeda berbahan komposit, yaitu : Faktor A (Seat Tube Angle) sebesar 85\% memiliki pengaruh yang sangat besar, dibandingkan dengan faktor C (Beban Pengendara) sebesar 10\%, selanjutnya untuk faktor B (Pergeseran Head Tube) memiliki pengaruh $1 \%$.
\end{abstract}

Kata kunci : rangka sepeda, komposit, metode taguchi, ANOVA

\begin{abstract}
Basically the criteria of a good frame is to have high strength and stiffness but light and have resistance to corrosion. Based on these criteria is used composite materials, which can be obtained better criteria than steel or aluminum frames, frames can be made stronger and lighter, but more importantly, the designer can control the characteristics of control and is not limited by the use of metal. The purpose of this research is to analyze the condition of optimum design of bicycle frame with the Taguchi method and analysis of ANOVA. Based on the analysis of data processing with the conditions of optimum design that provide voltage Von Mises (MPa) large is: A2 B2 C3 or do calculations with the design conditions using the Seat Tube Angle at 72o, by shifting Head Tube $0.2 \mathrm{~mm}$ and load the driver at $90 \mathrm{~kg}$, Calculation analysis by ANOVA to determine the effect of each factor to the calculation of Voltage Maximum on a bicycle made from composites, namely: A Factor (Seat Tube Angle) of $85 \%$ had an enormous influence, compared with $C$ factor (Expense rider) by $10 \%$, next to B factor (Shift Head Tube) has the effect of $1 \%$.
\end{abstract}

Keywords: bike frame, composite, Taguchi method, ANOVA 


\section{PENDAHULUAN}

Pada umumnya frame sepeda dibuat menggunakan material baja atau alumunium. Akan tetapi, akibat adanya kebutuhan dalam bentuk bersepeda seperti off-road, downhill racing, atau spending, dibutuhkan frame sepeda yang memadai untuk aktivitas-aktivitas tersebut, yaitu yang memiliki kekuatan tinggi tetapi ringan, sehingga beberapa produsen sepeda terkemuka membuat sepeda komposit.

Pada dasarnya kriteria frame yang baik adalah memilki kekuatan dan kekakuan yang tinggi tetapi ringan dan mempunyai ketahanan terhadap korosi. Berdasarkan kriteria tersebut digunakanlah material komposit, dimana dapat diperoleh kriteria yang lebih baik dibandingkan dengan frame baja atau alumunium, Frame dapat dibuat lebih kuat dan ringan, tetapi yang lebih penting, desainer dapat mengontrol karakteristik pengendalian dan tidak dibatasi oleh penggunaan metal.

Didalam penelitian ini akan dilakukan optimasi desain dari rangka sepeda dengan menggunakan bahan baku komposit, dengan memperhatikan kriteria pengujian-pengujian didalam pembuatan rangka sepeda dengan menggunakan metode eksperimen Taguchi.

\section{Permasalahan}

Berdasarkan Latar Belakang diatas akan dilakukuan Penelitian Mengenai kondisi optimum desain rangka sepeda dengan menggunakan desain rangka yang optimal dengan bantuan program Finite Elemen Analysis (FEA) seperti Software Pro Engineer.

Faktor yang digunakan dalam penelitian ini adalah: faktor pada dimensi rangka sepeda seperti: Seat Tube Angle (STA), Head Tube, beban pengendara yang diberikan untuk simulasi rangka sepeda.

\section{Perumusan Masalah Penelitian}

Untuk Menyelesaikan masalah diatas, penulis mencoba membuat batasan rumusan masalah dalam penelitian ini sebagai berikut :

1. Seberapa besar pengaruh faktor Beban Pengendara Terhadap Pergeseran Head Tube dan Seat Tube angel daripada rangka sepeda dengan menggunakan bahan baku komposit?

2. Kondisi optimum daripada Beban Pengendara Terhadap Pergeseran Head Tube dan Seat Tube angel rangka sepeda berbahan baku komposit dengan menggunakan metode Taguchi?

\section{Tujuan Penelitian}

Tujuan Utama yang diinginkan dicapai dari penelitian ini ada 2 (dua) yaitu sebagai berikut :

1. Mempelajari seberapa besar pengaruh faktor Beban Pengendara Terhadap Pergeseran Head
Tube dan Seat Tube angel rangka sepeda berbahan baku komposit.

2. Menganalisa kondisi optimum Beban Pengendara Terhadap Pergeseran Head Tube dan Seat Tube angel rangka sepeda dengan metode Taguchi dan analisis ANOVA.

\section{Manfaat Penelitian}

Dari hasil penelitian ini diharapkan akan mempunyai manfaat teoritis yaitu :

1. Optimasi desain rangka sepeda berbahan baku komposit. Sehingga dapat memperbaiki perancangan rangka sepeda yang sudah ada.

2. Apabila dilakukan optimasi desain dari rangka sepeda tersebut dapat meningkatkan proses produksi dan juga biaya material bahan baku pembuatan rangka sepeda.

\section{METODOLOGI PENELITIAN}

Untuk memperoleh gambaran yang jelas, tentang langkah-langkah pemecahan masalah, maka dibuatlah diagram alir pemecahan masalah, seperti yang ditunjukkan pada Gambar 1. dibawah ini:

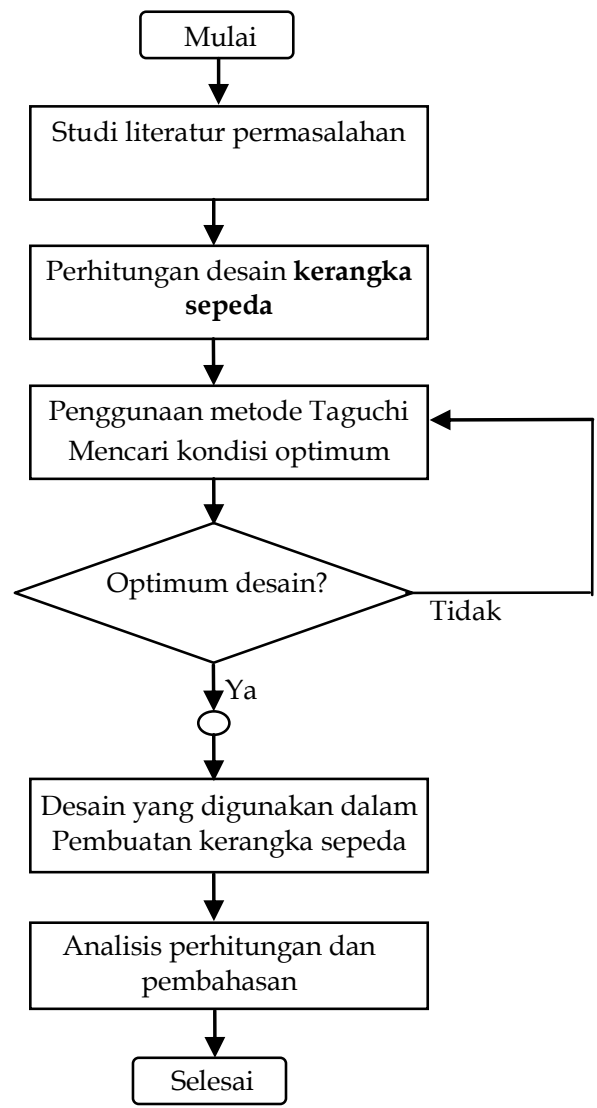

Gambar 1. Diagram alir penelitian

\section{Tempat Penelitian}

Pascasarjana Teknik Mesin Universitas Pancasila, obyek yang diteliti adalah desain kerangka sepeda gunung dengan menggunakan material komposit. 
Ahmad Yakub, Djoko W. Karmiadji, Anwar Ilmar Ramadhan : Optimasi Desain Rangka Sepeda Berbahan Baku Komposit Berbasis Metode Anova

Jurnal Teknologi. 8 (1) pp 17-22 @ 2016

\section{Metode Penelitian}

Metode yang digunakan dalam optimasi desain kerangka sepeda ini adalah dengan memperhatikan dan menggunakan dari faktor dimensi dari rangka sepeda gunung. Selanjutnya dilakukan perhitungan untuk menentukan kondisi optimum dengan menggunakan metode Taguchi.

Dengan menggunakan metode eksperimen Taguchi dapat dibuatkan Tabel 1. yaitu tabel yang memuat jumlah variabel/faktor dari ekperimen dan level yang berkaitan.

Tabel 1. Variabel/faktor dan level di metode Taguchi

\begin{tabular}{|l|l|l|l|l|}
\hline Kode & $\begin{array}{l}\text { Variabel Bebas / } \\
\text { Faktor }\end{array}$ & $\begin{array}{l}\text { Level } \\
\mathbf{1}\end{array}$ & $\begin{array}{l}\text { Level } \\
\mathbf{2}\end{array}$ & $\begin{array}{l}\text { Level } \\
\mathbf{3}\end{array}$ \\
\hline $\mathrm{A}$ & $\begin{array}{l}\text { Seat Tube Angle } \\
(\mathrm{STA})\left(^{\circ}\right)\end{array}$ & 62 & 72 & 82 \\
\hline $\mathrm{B}$ & $\begin{array}{l}\text { Pergeseran Head } \\
\text { Tube }(\mathrm{mm})\end{array}$ & 0.1 & 0.2 & 0.3 \\
\hline $\mathrm{C}$ & $\begin{array}{l}\text { Berat pengendara } \\
(\mathrm{kg})\end{array}$ & 70 & 80 & 90 \\
\hline
\end{tabular}

\section{ANALISIS DATA DAN HASIL PENELITIAN}

\section{Analisis data}

Analisis data pada penelitian ini terdiri dari dua tahap, yaitu tahap pengumpulan data dan tahap pengolahan data. Pengumpulan data meliputi kegiatan pengujian dan pengambilan data. Pengolahan data meliputi pengelompokan data, analisis variasi, identifikasi factor dominan, dan memperkirakan hasil yang optimum.

\section{Uji Frame (Rangka) Sepeda}

Tabel 2. Fraksi massa spesimen

\begin{tabular}{|c|l|l|l|l|lr|}
\hline No & $\begin{array}{l}\text { Jumlah } \\
\text { Lapisan } \\
\text { (Layer) }\end{array}$ & $\begin{array}{l}\text { Massa } \\
\text { Total } \\
\text { gram) }\end{array}$ & $\begin{array}{l}\text { Massa } \\
\text { Serat } \\
\text { gram) }\end{array}$ & $\begin{array}{l}\text { Massa } \\
\text { Resin } \\
\text { gram) }\end{array}$ & $\begin{array}{l}\text { Fraksi } \\
\text { massa } \\
\text { (Serat:resin) }\end{array}$ \\
\hline 1 & 2 & 74.60 & 44.20 & 30.40 & $\begin{array}{l}59.20 \\
40.80\end{array}$ & $:$ \\
\hline 2 & 4 & 130.60 & 88.30 & 42.30 & $\begin{array}{l}67.60 \\
32.40\end{array}$ & $:$ \\
\hline 3 & 6 & 550.00 & 300.00 & 250.00 & $\begin{array}{l}55.00 \\
45.00\end{array}$ \\
\hline
\end{tabular}

Fraksi volume spesimen

Tabel 3. Fraksi volume Spesimen

\begin{tabular}{|l|l|l|l|l|l|l|}
\hline $\begin{array}{l}\mathrm{N} \\
\mathrm{o}\end{array}$ & $\begin{array}{l}\text { Jumla } \\
\mathrm{h} \\
\text { Lapisa } \\
\mathrm{n} \\
\text { (Layer } \\
)\end{array}$ & $\begin{array}{l}\text { Volu } \\
\text { me } \\
\text { serat } \\
(\mathrm{cc})\end{array}$ & $\begin{array}{l}\text { Volu } \\
\text { me } \\
\text { resin } \\
(\mathrm{cc})\end{array}$ & $\begin{array}{l}\text { Volu } \\
\text { me } \\
\text { Total } \\
(\mathrm{cc})\end{array}$ & $\begin{array}{l}\text { Fraksi } \\
\text { Volu } \\
\text { me }\end{array}$ & $\begin{array}{l}\text { Massa } \\
\text { jenis } \\
\text { kompo } \\
\text { sit } \\
\left(\mathrm{gr} / \mathrm{cm}^{3}\right. \\
)\end{array}$ \\
\hline 1 & 2 & 17.40 & 27.40 & 44.80 & $39: 61$ & 1.66 \\
\hline 2 & 4 & 34.70 & 38.10 & 72.86 & $48: 52$ & 1.80 \\
\hline 3 & 6 & $\begin{array}{l}118.1 \\
1\end{array}$ & $\begin{array}{l}225.2 \\
2\end{array}$ & $\begin{array}{l}343.3 \\
3\end{array}$ & $34: 66$ & 1.60 \\
\hline
\end{tabular}

Dengan $\rho_{\text {serat }}$ WR $400=2.54\left[\mathrm{gr} / \mathrm{cm}^{3}\right]$ dan $\rho_{\text {resin }}=$ $1.11\left[\mathrm{gr} / \mathrm{cm}^{3}\right]$
Hasil uji tarik pada ketebalan 2 layer

Tabel 4. Hasil Uji Tarik pada Ketebalan 2 Layer

\begin{tabular}{|c|c|c|c|c|c|c|}
\hline $\begin{array}{l}\mathrm{N} \\
\mathrm{o}\end{array}$ & $\begin{array}{l}\text { Juml } \\
\text { ah } \\
\text { Lapis } \\
\text { an } \\
\text { (Laye } \\
\text { r) }\end{array}$ & $\begin{array}{l}\text { Leb } \\
\text { ar } \\
(\mathrm{m} \\
\mathrm{m})\end{array}$ & $\begin{array}{l}\text { Teb } \\
\text { al } \\
\text { (m } \\
\text { m) }\end{array}$ & $\begin{array}{l}\text { Beban } \\
\text { Maksim } \\
\text { um (kg) }\end{array}$ & $\begin{array}{l}\text { Tegang } \\
\text { an } \\
\text { Maks } \\
(\mathrm{kg} / \mathrm{m} \\
\mathrm{m} 2)\end{array}$ & $\begin{array}{l}\text { Modul } \\
\text { us } \\
\text { Youn } \\
\text { g } \\
(\mathrm{MPa})\end{array}$ \\
\hline 1 & 2 & 8.30 & $\begin{array}{l}1.1 \\
0\end{array}$ & 234.80 & 25.60 & $\begin{array}{l}2122 . \\
00\end{array}$ \\
\hline 2 & 2 & 7.00 & $\begin{array}{l}1.1 \\
0\end{array}$ & 171.90 & 22.30 & $\begin{array}{l}1951 . \\
20\end{array}$ \\
\hline 3 & 2 & 7.20 & $\begin{array}{l}1.1 \\
0\end{array}$ & 167.90 & 21.20 & $\begin{array}{l}2387 . \\
20\end{array}$ \\
\hline \multicolumn{2}{|c|}{ Rata-rata } & 7.50 & $\begin{array}{l}1.1 \\
0\end{array}$ & 191.50 & 23.00 & $\begin{array}{l}2153 . \\
50\end{array}$ \\
\hline
\end{tabular}

tegangan maksimum sebesar $23.00 \mathrm{~kg} / \mathrm{mm}^{2}$ atau sekitar $225.40 \mathrm{MPa}$ dan kekuatan tarik maksimum rata-rata sebesar $191.50 \mathrm{~kg}$.

\section{Hasil uji tarik pada ketebalan 4 layer}

Tabel 5. Hasil Uji Tarik pada Ketebalan 4 Layer

\begin{tabular}{|l|l|l|l|l|l|l|}
\hline $\begin{array}{l}\mathrm{N} \\
\mathrm{o}\end{array}$ & $\begin{array}{l}\text { Jumla } \\
\mathrm{h} \\
\text { Lapis } \\
\text { an } \\
\text { (Laye } \\
\mathrm{r})\end{array}$ & $\begin{array}{l}\text { Leb } \\
\text { ar } \\
(\mathrm{mm} \\
)\end{array}$ & $\begin{array}{l}\text { Teb } \\
\text { al } \\
(\mathrm{mm} \\
)\end{array}$ & $\begin{array}{l}\text { Beban } \\
\text { Maksimu } \\
\mathrm{m} \mathrm{(kg)}\end{array}$ & $\begin{array}{l}\text { Tegang } \\
\text { an } \\
\text { Maks } \\
(\mathrm{kg} / \mathrm{mm} \\
2\end{array}$ & $\begin{array}{l}\text { Modul } \\
\text { us } \\
\text { Young } \\
(\mathrm{MPa})\end{array}$ \\
\hline 1 & 4 & 6.70 & 1.95 & 313.30 & 235.20 & $\begin{array}{l}14340 . \\
00\end{array}$ \\
\hline 2 & 4 & 7.25 & 1.95 & 288.70 & 200.30 & $\begin{array}{l}15470 . \\
00\end{array}$ \\
\hline 3 & 4 & 7.20 & 1.95 & 343.10 & 239.70 & $\begin{array}{l}15010 . \\
00\end{array}$ \\
\hline \multicolumn{2}{|l|}{ Rata-rata } & 7.05 & 1.95 & 315.00 & 225.10 & $\begin{array}{l}14940 . \\
00\end{array}$ \\
\hline
\end{tabular}

Tegangan maksimum sebesar $225.10 \mathrm{~kg} / \mathrm{mm}^{2}$ dan kekuatan tarik maksimum rata-rata sebesar 315.00 $\mathrm{kg}$.

Hasil uji tarik pada ketebalan 6 layer

Tabel 6. Hasil Uji Tarik pada Ketebalan 6 Layer

\begin{tabular}{|l|l|l|l|l|l|l|}
\hline $\begin{array}{l}\mathrm{N} \\
\mathrm{o}\end{array}$ & $\begin{array}{l}\text { Jumla } \\
\mathrm{h} \\
\text { Lapis } \\
\text { an } \\
(\text { Laye } \\
\mathrm{r})\end{array}$ & $\begin{array}{l}\text { Leb } \\
\text { ar } \\
(\mathrm{mm} \\
)\end{array}$ & $\begin{array}{l}\text { Teb } \\
\text { al } \\
(\mathrm{mm} \\
)\end{array}$ & $\begin{array}{l}\text { Beban } \\
\text { Maksimu } \\
\mathrm{m}(\mathrm{kg})\end{array}$ & $\begin{array}{l}\text { Tegang } \\
\text { an } \\
\text { Maks } \\
(\mathrm{kg} / \mathrm{mm} \\
2)\end{array}$ & $\begin{array}{l}\text { Modul } \\
\text { us } \\
\text { Young } \\
(\mathrm{MPa})\end{array}$ \\
\hline 1 & 6 & 8.20 & 4.70 & 701.50 & 178.60 & $\begin{array}{l}13030 . \\
00\end{array}$ \\
\hline 2 & 6 & 7.55 & 4.35 & 734.10 & 219,30 & $\begin{array}{l}10510 . \\
00\end{array}$ \\
\hline 3 & 6 & 6.90 & 4.35 & 567.40 & 185.40 & $\begin{array}{l}11890 . \\
00\end{array}$ \\
\hline \multicolumn{2}{|l|}{ Rata-rata } & 7.55 & 4.47 & 667.70 & 194.40 & $\begin{array}{l}11810 . \\
00\end{array}$ \\
\hline
\end{tabular}

Tegangan maksimum sebesar $194.40 \mathrm{~kg} / \mathrm{mm}^{2}$ dan kekuatan tarik maksimum rata-rata sebesar 667.70 $\mathrm{kg}$. 
Tabel 7. Kekuatan tarik sesuai dengan jumlah lapisan

\begin{tabular}{|l|l|l|}
\hline $\begin{array}{l}\text { Jumlah } \\
\text { Lapisan } \\
\text { (Layer) }\end{array}$ & $\begin{array}{l}\text { Beban } \\
\text { Maksimum } \\
(\mathrm{kg})\end{array}$ & $\begin{array}{l}\text { Tegangan Maks } \\
\left(\mathrm{kg} / \mathrm{mm}^{2}\right)\end{array}$ \\
\hline 2 & 191.50 & 225.40 \\
\hline 4 & 315.00 & 225.10 \\
\hline 6 & 667.70 & 194.40 \\
\hline
\end{tabular}

Grafik hubungan antara jumlah lapisan terhadap kekuatan tarik [kg] dapat dilihat pada Gambar 2.

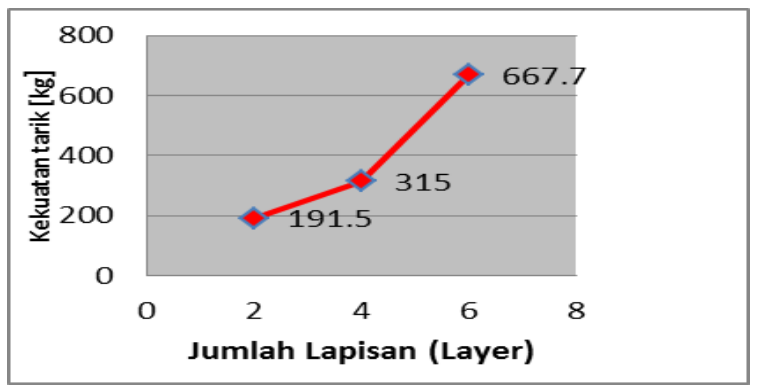

Gambar 2. Hubungan antara lapisan terhadap kekuatan tarik

Grafik hubungan antara jumlah lapisan terhadap tegangan maksimum $\left[\mathrm{kg} / \mathrm{mm}^{2}\right]$ dapat dilihat pada Gambar 3.

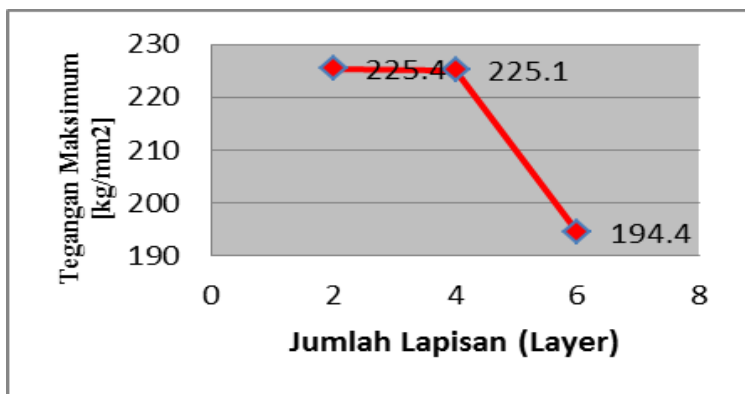

Gambar 3. Hubungan antara lapisan terhadap tegangan maksimum

\section{Perbandingan hasil uji tarik}

Tabel 8. Data perbandingan hasil uji tarik

\begin{tabular}{|l|l|l|}
\hline $\begin{array}{l}\text { Jumlah } \\
\text { Lapisan } \\
\text { (Layer) }\end{array}$ & $\begin{array}{l}\text { Tegangan Maks } \\
\text { (Software Pro } \\
\text { Engineer) (MPa) }\end{array}$ & $\begin{array}{l}\text { Tegangan } \\
\text { Maks (MPa) }\end{array}$ \\
\hline 2 & 227.19 & 225.40 \\
\hline 4 & 224.78 & 225.10 \\
\hline 6 & 194.22 & 194.40 \\
\hline
\end{tabular}

Tabel 9. Pengaruh rata-rata STA $62^{\circ}$ terhadap tegangan maksimum

\begin{tabular}{|c|l|l|}
\hline \multirow{2}{*}{ No. pengujian } & Level \\
\cline { 2 - 3 } & $\begin{array}{l}\text { Seat Tube Angle } \\
(\text { STA })\left({ }^{\circ}\right)\end{array}$ & $\begin{array}{l}\text { Tegangan Von Mises } \\
(\mathrm{MPa})\end{array}$ \\
\hline 1 & 62 & 219.23 \\
\hline 2 & 62 & 223.04 \\
\hline 3 & 62 & 231.37 \\
\hline Rata-Rata & 224.55 \\
\hline
\end{tabular}

Tabel 10. Pengaruh rata-rata faktor terhadap masing-masing level

\begin{tabular}{|r|l|c|c|}
\hline No & \multicolumn{1}{|c|}{ Uraian } & Notasi & $\begin{array}{l}\text { Tegangan Von } \\
\text { Misses (MPa) }\end{array}$ \\
\hline 1 & Pengaruh rata-rata STA 62 $^{\circ}$ & A1 & 224.55 \\
\hline 2 & Pengaruh rata-rata STA 72 $^{\circ}$ & A2 & 252.33 \\
\hline 3 & Pengaruh rata-rata STA 82 & A3 & 250.20 \\
\hline 4 & $\begin{array}{l}\text { Pengaruh rata-rata } \\
\text { pergeseran HT 0.1 mm }\end{array}$ & B1 & 239.80 \\
\hline 5 & $\begin{array}{l}\text { Pengaruh rata-rata } \\
\text { pergeseran HT 0.2 mm }\end{array}$ & B2 & 242.36 \\
\hline 6 & $\begin{array}{l}\text { Pengaruh rata-rata } \\
\text { pergeseran HT 0.3 mm }\end{array}$ & B3 & 244.92 \\
\hline 7 & $\begin{array}{l}\text { Pengaruh rata-rata beban } \\
\text { pengendara 70kg }\end{array}$ & C1 & 238.58 \\
\hline 9 & $\begin{array}{l}\text { Pengaruh rata-rata beban } \\
\text { pengendara 80kg }\end{array}$ & C2 & 239.95 \\
\hline pengaruh rata-rata beban & C3 & 248.54 \\
\hline
\end{tabular}

Tabel 11. Kondisi optimum dari hasil perhitungan dengan metode Taguchi

\begin{tabular}{|l|l|l|l|l|}
\hline $\begin{array}{l}\text { Kondisi } \\
\text { Desain }\end{array}$ & $\begin{array}{l}\text { Seat } \\
\text { Tube } \\
\text { Angle } \\
\left(\text { STA) }\left(^{\circ}\right)\right.\end{array}$ & $\begin{array}{l}\text { Pergeseran } \\
\text { Head Tube } \\
(\mathrm{mm})\end{array}$ & $\begin{array}{l}\text { Berat } \\
\text { pengenda } \\
\text { ra }(\mathrm{kg})\end{array}$ & $\begin{array}{l}\text { Tegangan } \\
\text { Von } \\
\text { Mises } \\
(\mathrm{MPa})\end{array}$ \\
\hline 5 & 72 & 0.2 & 90 & 259.53 \\
\hline
\end{tabular}

\section{Diagram Body Bebas}

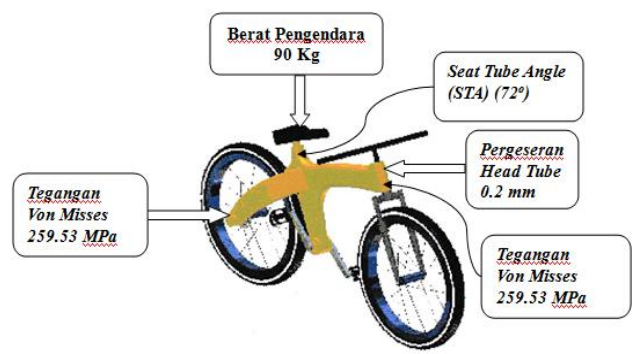

Gambar 4. Pemodelan hasil perhitungan

Diagram perhitungan ANOVA untuk perhitungan tegangan maksimum terhadap besarnya pengaruh dari masing-masing faktor.

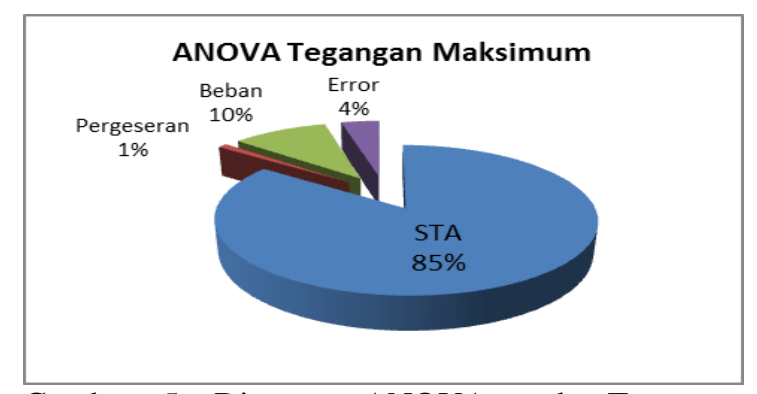

Gambar 5. Diagram ANOVA pada Tegangan Maksimum 
Ahmad Yakub, Djoko W. Karmiadji, Anwar Ilmar Ramadhan : Optimasi Desain Rangka Sepeda Berbahan Baku Komposit Berbasis Metode Anova

Jurnal Teknologi. 8 (1) pp 17-22 @ 2016

Tabel 12. Kondisi optimum dari hasil perhitungan dengan metode Taguchi

\begin{tabular}{|l|l|l|l|l|}
\hline $\begin{array}{l}\text { Kondisi } \\
\text { Desain }\end{array}$ & $\begin{array}{l}\text { Seat } \\
\text { Tube } \\
\text { Angle } \\
(\text { STA }) \\
\left({ }^{\circ}\right)\end{array}$ & $\begin{array}{l}\text { Pergeseran } \\
\text { Head } \\
\text { Tube } \\
(\mathrm{mm})\end{array}$ & $\begin{array}{l}\text { Berat } \\
\text { pengendara } \\
(\mathrm{kg})\end{array}$ & $\begin{array}{l}\text { Tegangan } \\
\text { Von Mises } \\
(\mathrm{MPa})\end{array}$ \\
\hline 5 & 72 & 0.2 & 90 & 259.53 \\
\hline
\end{tabular}

Gambar Tampilan (Frame) rangka sepeda Komposit tampak atas seperti pada Gambar 6.

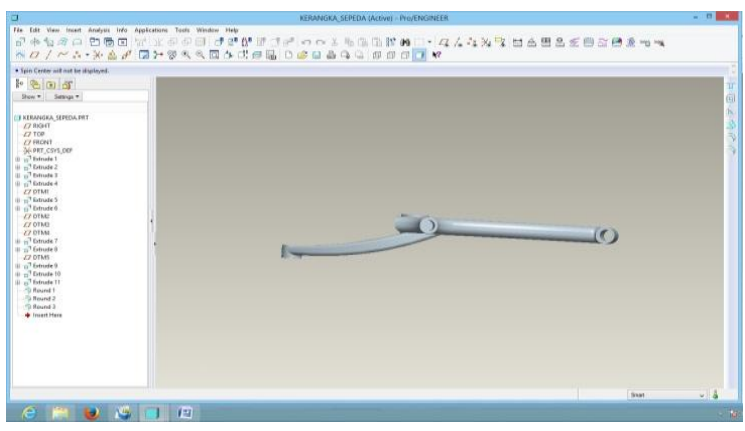

Gambar 6. Frame rangka sepeda komposit tampak atas

Gambar tampak samping rangka sepeda komposit dapat dilihat pada Gambar 7.

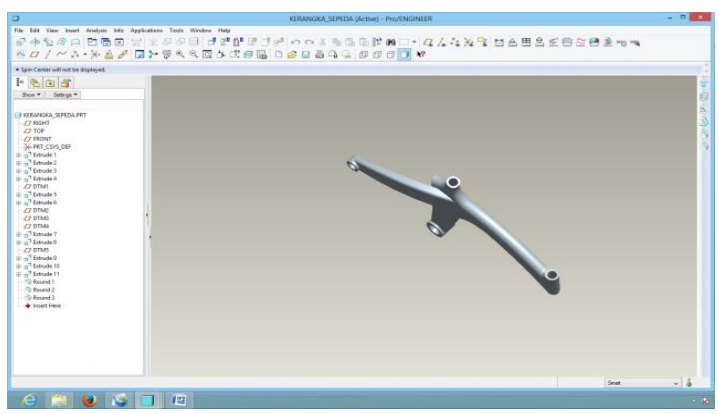

Gambar 7. Frame rangka sepeda komposit tampak samping

Gambar analisis perbandingan pembebanan terhadap tegangan Von Misses pada rangka sepeda komposit dapat dilihat pada Gambar 8.

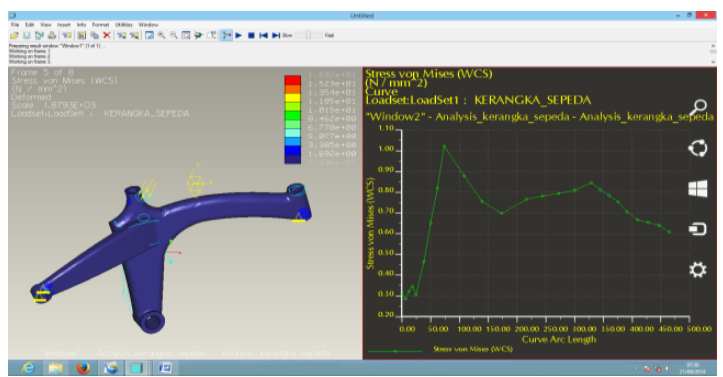

Gambar 8. Analisis perbandingan pembebanan terhadap tegangan Von Misses
Gambar posisi analisis grafik tegangan Von Misses pada rangka sepeda komposit dapat dilihat pada Gambar 9.

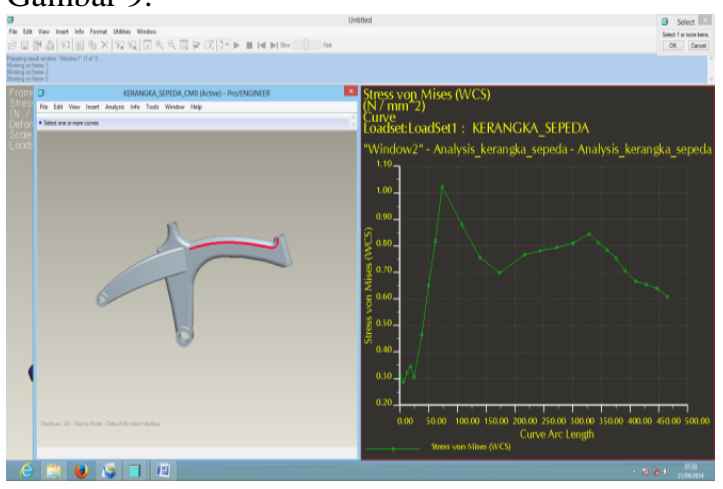

Gambar 9. Analisis grafik tegangan Von Misses terhadap rangka sepeda komposit

Gambar Analisis Tegangan dan Regangan Pada Rangka Sepeda Komposit dapat dilihat pada Gambar 10.

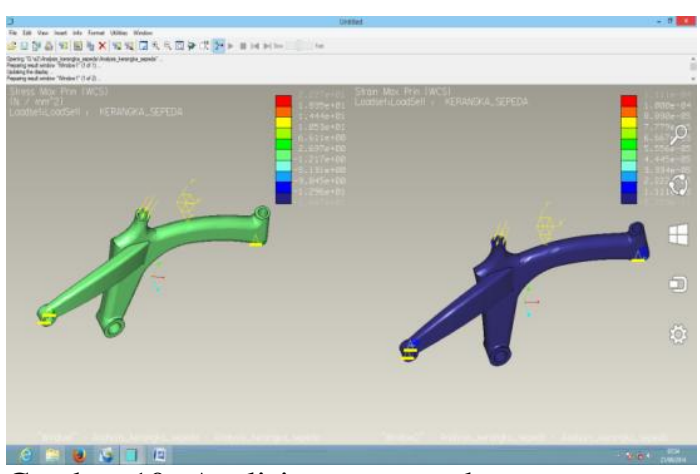

Gambar 10. Analisis tegangan dan regangan pada rangka sepeda komposit

Gamba Analisis Pergeseran dan Tekanan Pada Rangka Sepeda Komposit dapat dilihat Gambar 11.

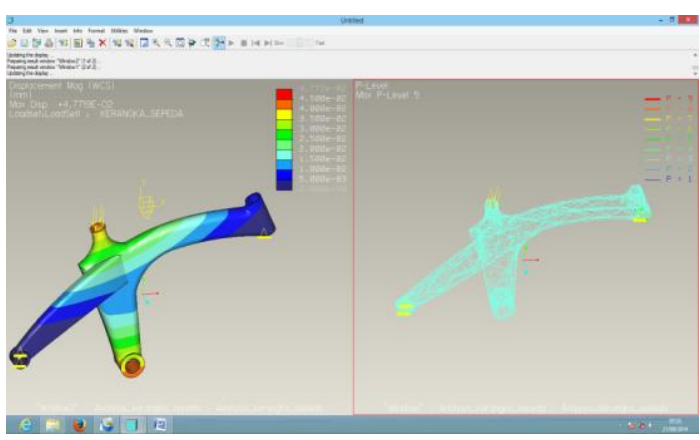

Gambar 11. Analisis pergeseran dan tekanan pada rangka sepeda komposit

\section{KESIMPULAN DAN SARAN}

\section{Kesimpulan}

Berdasarkan analisa hasil pengolahan data dengan menggunakan metode Taguchi dan 
ANOVA dapat di ambil kesimpulan sebagai berikut :

1. Dari hasil observasi di atas dapat dicermati bahwa kondisi desain optimum yg memberikan Tegangan Von Mises (MPa) yang besar adalah : A2 B2 C3 atau yang dilakukan perhitungan dengan kondisi desain menggunakan Seat Tube Angle sebesar $72^{\circ}$, dengan pergeseran Head Tube $0.2 \mathrm{~mm}$ dan beban pengendara sebesar $90 \mathrm{~kg}$.

2. Analisis perhitungan dengan ANOVA untuk mengetahui pengaruh masing-masing faktor terhadap perhitungan Tegangan Maksimum pada sepeda berbahan komposit, yaitu :

2.a. Faktor A (Seat Tube Angle) sebesar $85 \%$ memiliki pengaruh yang sangat besar, dibandingkan dengan faktor C (Beban Pengendara) sebesar $10 \%$, selanjutnya untuk faktor B (Pergeseran Head Tube) memiliki pengaruh $1 \%$

2.b. Dari hasil Simulasi dengan menggunakan software Pro Engineer besarnya tegangan von misses yang paling besar $1.5 \mathrm{~N} / \mathrm{mm}^{2}$ pada jarak $70 \mathrm{~mm}$ dari dudukan stang sepeda. Regangan yang terjadi pada kerangka sepeda merata ke seluruhan bagian yaitu sebesar $6,611 \mathrm{~N} / \mathrm{mm}^{2}$, sedangkan tegangan yang terjadi tidak merata, besarnya tegangan yang paling besar $2.222 \mathrm{~N} / \mathrm{mm}^{2}$, pergeseran dan tekanan pada rangka sepeda dimana terjadi pergeseran dan tekanan yang terjadi paling besar yaitu $7,7719 \times 10^{-2}$.

\section{Saran}

Untuk saran yang dapat diberikan dari hasil penelitian untuk dilakukan penelitian lebih lanjut adalah sebagai berikut: (1) Untuk penelitian lebih lanjut dapat dilakukan dengan menggunakan material komposit yang berbeda. (2) Dalam penelitian lanjutan dapat menggunakan metode full factorial dengan berbagai macam rangka sepeda yang berbeda. Sehingga dapat memberikan perbandingan hasil kondisi optimum dibandingkan rangka sepeda yang dikerjakan dalam penelitian ini.

\section{DAFTAR PUSTAKA}

Aisah, N., dkk, 2004, Pembuatan Komposit Polimer Berpenguat Serat Sintetik Untuk Bahan Genteng, Jurnal Sains Materi Indonesia, Vol. 5 No 3

Batan, I. M. L., dkk, 2010, Rancang Bangun Rangka Fleksibel Dalam Upaya Optimasi Geometri Rangka Sepeda, Institut Teknologi Sepuluh Nopember, Surabaya

Chadry, R., 2011, Analisa Getaran Hasil Desain Sepeda Lipat dengan Pemodelan Software,
Jurusan Teknik Mesin, Politeknik Negeri Padang, Padang

Ross, P. J., 1996, Taguchi Techniques for Quality Engineering. $2^{\text {nd }}$ Edition. McGraw Hill. New York.

Maleque, M.A., and Dyuti, S., 2010, Materials Selection of A Bicycle Frame Using Cost Per Unit Property and Digital Logic Methods, International Journal of Mechanical and Material Engineering

Pramono, A., 2011, Komposit sebagai Trend Teknologi Masa Depan (Kajian Teori dan Aplikasi), Fakultas Teknik Metalurgi dan Material, Universitas Sultan Ageng Tirtayasa, Serang

Widodo, B., 2008, Analisa Sifat Mekanik Komposit Epoksi Dengan Penguat Serat Pohon Aren (Ijuk) Model Lamina Berorientasi Sudut Acak (Random), Jurnal Teknologi Technoscientia, Vol. 1 No 1

Tang, H. C., dkk, 2000, Fatigue Model For FiberReinforced Polymeric Composites, Journal of Materials in Civil Engineering, Vol. 12 No 2.

http://id.wikipedia.org/wiki/sepeda. diunduh pada tanggal: 07 Januari 2013

http://id.wikipedia.org/wiki/sepeda_gunung. diunduh pada tanggal: 07 Januari 2013

http://material12-its.blogspot.com/2011/09/bahankomposit.html, diunduh pada tanggal: 11 Januari 2013 